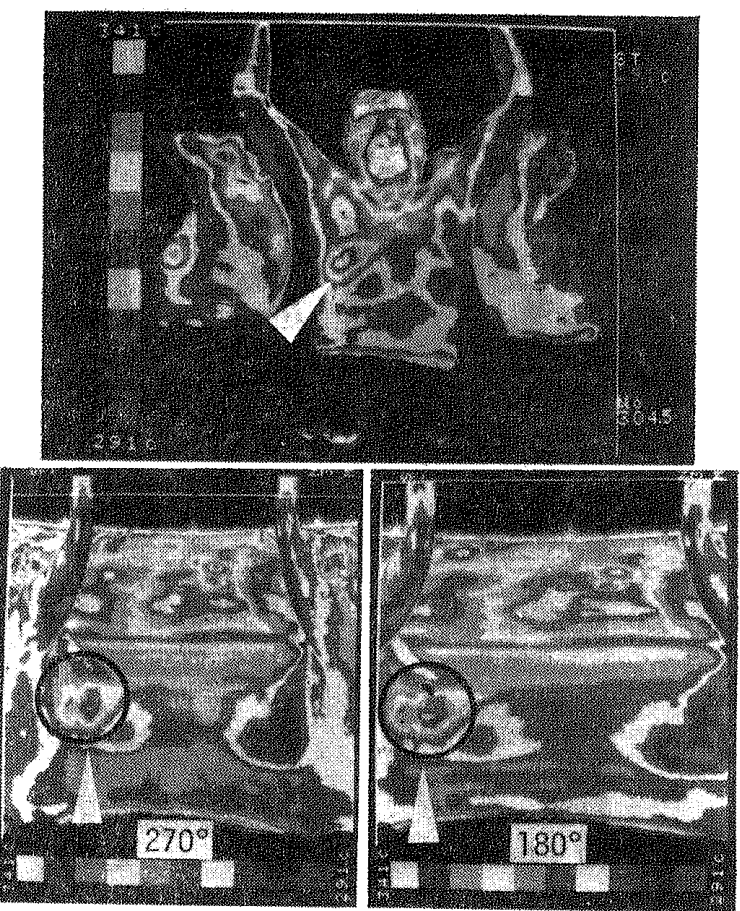

図 6

三面像の構成が得られる位置に撮影距離を選定 する. (6)ピントを合わせる（理想的には正面像 と側面像の中間位に合わせるが，いずれに合わ せても実用上は問題ない)。(9通常の面走 查で 撮影する。

2) パノラミック サーモグラフィ: (1)サー モカメラの開口部に $\mathrm{H}-\mathrm{V}$ 変換鏡を装着し，こ れをカメラ台の当該ポジションに装着する。(2) 被写体の中心軸を回転軸に一致させ, 測定位に 設定する. (3)サーモカメラの高さを調節する.

(4) $\mathrm{H}-\mathrm{V}$ 変換鏡を介して被写体を面走査し，映 像を監視しながら, 回転べースの回転位置を調 節して，正中線を画面の中央に一致させる。（5)
適切な展開像の画像構成が得られるところに撮 影距離を調節し，ピントを合わせる。（6)走查線 が正中線に達したところで，面走查を線走查に 切り替える。これでサーモカメラは常に回転中 心軸止を線走查することになる。(7) 被写範囲 （被写回転角度）を決め，それに対応する $\mathrm{Tf}$ と $\operatorname{Tr}$ を選定する（被写範囲は $\operatorname{Tf}$ と $\operatorname{Tr}$ の 比によって変えられ, 被写回転角度は $360 \times \mathrm{Tf}$ / Tr 度である)。(8)被写範囲に対応する始動位 置に椅子の回転位㯰を設定する。（9)スートボ タンを入れると自動的にパノラミックサーモグ ラムが得られる。

\section{3. 臨床応用之本法の考案}

図 6 に右側乳癌の展開サーモグラムの 1 例を 示す (カラー表示の白黒写真). 本法の特徵は (1)被写範国が広いので, 異常部検出エラ一の危 険性が少なく，体表温度分布の 3 次元的観察が できる（本例では患部の高温域が，右乳房に院 局し，他所へは波及していないのがわかる).

(2)三面法では反射鏡の開き角度に応じて，側面 像の被写域が変えられる。(3)パノラミック法で は体表温度分布を連続的に観察することがで き，被写範囲も全周域にまで変えられる。また それに応じて，展開軸方向の像拡大率が変わ り，拡大率の大きいところでは熱画像の形状的 精查が行える（本例ではパノラミック像で, 患 部の形態的特徵が解明されている)。また測光 軸が被写体の中心軸に向いているので，測光角 度に基づく測定誤差の影響が少ない，など本法 は従来法に勝る長所が多い。

\title{
99. コンピュータ制卸による平衡機能検査装置
}

林

弊社においては平衡機能検査装置の $\mathrm{CPU}$ :

近年コンピュータの普及に伴い，医療機器一 の導入は，めざましいものがある。

* 永島医科器械侏
ステム化の一環として，CPU 制御による多用 途の視性刺激装置 CR-58 型を完成したのでそ の概要を解説する. 


\section{1. 本装置開発の目的}

平衡機能検查の中で，視性眼振刺激検查 $(\mathrm{O}$ $\mathrm{KN})$, 視標追跡検査 (ETT), 跳躍眼運動検査 (Saccade)，などの検查は，脳幹および小脳を 主とした，一連の中枢性の病変を知る上で，最 も重要なものとされているままたそれらの刺激 検査によって得られたデータを CPUで分析処 理を行うた的汇は，その刺激機能の精度と安定 性の高いことが，必然要求される，同時にそれ らの数種の刺激機能を， 1 台の装置に兼社備え ることは，従来からのニ一ズであり，われわれ メーカの目標でもあった，それらのほとんどの 機能を満足し得る装置の実現を目標として，設 計製作したものである.

\section{2. 本装置の特長}

a 刺激運動モードの設定が容易で，その精度 および再現性を飛躍的に向上することができ た.

b 従来は数種の装置を必要としたが， CPU の導入により，幾通りものモードから選択で き，な打回転角速度，角加速度，周期などの 設定範囲を，大幅に搪大することができた。 c 運動モードを，制御パネル操作によってプ ログラム化することができ，ステートメント を幾種類もプログラムすることにより，連続 的に運動モードを実行させることができる.

d CPU 制御で精度が高いため, 回転装置 と の同軸組み合わせ使用が可能で，同期性も良 好である。

e データ分析処理システムと接続でき，同時 に，その指令に従って運動モードを実行し

て, 眼球運動之刺激運動との相関を, みるこ とができる。

\section{3. 本装置使用の効果}

以上記述したごとく装置の性能を高得たこ そにより，CPU 分析处理が実用化に 向かって いる，平衡神経科学の領域において，十分にそ のニーズに応え得る装置であるらと考えられ る.

\section{4. 構造と安全性}

CPU 制御を用いたことにより，装置全体の 小型軽量化に成功したため, 安全性信頼性を十 分に高めることができた.

\section{0. 全身複 合理学療法機}

本格的高龄化社会の到来これに伴う老人医療 対策と各病医院において高龄患者層が非常なウ エイトを占めています。複雑化する交通事故・ 職業病・生活様式の変化に上る体質虚弱化・内 藏疾患・過体重・不良姿勢に上る腰痛症・慢性 疲労怯うっ血や貧血を生み、いわゆるこう症状 も増加してくる．オスピナレータ・インペリア ルはこのような症状に最適な治療効果を上げ る. ローラ方式の器種は他社にもあるが，イン ペリアルの三又ローラは患者に不快感・苦痛が なくローラの回転数が 1 分間 72 回転・脈拍数と

* 懒大島製作所
同リズムなのでソフトで新鮮な刺激を与える。 全自動プログラムは介助を要せず各機能（8機 能）が複合的に作用し，患者は装具に頼ること なくリラックスした状態で医療マッサージ効果 が得られる．さらに患者が乗り降り楽な高さ60 $\mathrm{cm}$ のベッドェリアなど，患者の身になった設 計である。操作はボタン 1 つのワンタッチであ り医療の省力化汇役立つ,インペリアルの最大 特徴は頸肩刺激ができ，他ローラ方式の器種と 異なる特徵である。頸骨動脈の蛇行改善により 脳血管循環改善に大きく作用する。 むちろんイ ンペリアルは保険点数請求ができる，1）消炎 鎮痛を目的とする理学療法（30点）2）繁引療 